\title{
Pengenalan Orang Patut dalam Tradisi Melayu Riau Pada Siswa di SMP Negeri 3 Kampar Kiri Tengah Kabupaten Kampar
}

\author{
Amanan*, Hermansyah**, Juswandi*** \\ Fakultas Ilmu Budaya, Universitas Lancang Kuning \\ *Email: amanan@unilak.ac.id
}

\begin{abstract}
The introduction of Orang Patut in the Riau Malay tradition at various levels in schools today is very minimal. Likewise in the older generation, only very few people know and understand about Orang Patut in the Riau Malay Tradition. In fact, people have a very important role in various things such as marriage, circumcision of the Apostle, dispute resolution, settlement of fights, traditional events, treating the sick and so on. This problem is also felt by the millennial generation in various existing educational institutions, such as students of SMP Negeri 3 Kec.Kampar Kiri Tengah. Until now, the introduction of Orang Patut in the Riau Malay tradition to students in various schools is still lacking, so that many in today's generation do not know the Orang Patut in the Riau Malay tradition. Moreover, those who can ground or preserve it.
\end{abstract}

Keywords: Introduction, Orang Patut, Riau Malay Tradition.

\begin{abstract}
Abstrak
Pengenalan Orang Patut dalam tradisi Melayu Riau di berbagai tingkatan di sekolah pada masa sekarang sangat minim. Begitu juga pada generasi tua, hanya sedikit sekali orang yang mengetahui dan paham tentang Orang Patut dalam Tradisi Melayu Riau. Padahal, Orang Patut sangat berperan dalam berbagai hal seperti pernikahan, Sunat Rasul, penyelesaian sengketa, peyelesaian perkelahian,acara-acara adat, mengobati yang sakit dan lain sebagainya. Permasalahan tersebut juga dirasakan generasi milenial di berbagai lembaga pendidikan yang ada, seperti di siswa SMP Negeri 3 Kec.Kampar Kiri Tengah. Pengenalan tentang Orang Patut dalam tradisi Melayu Riau pada peserta didik yang ada di berbagai sekolah sampai saat ini masih sangat kurang dilakukan, sehingga banyak di kalangan generasi zaman sekarang yang tidak kenal dengan Orang Patut dalam tradisi Melayu Riau. Apalagi yang bisa membumikan atau melestarikan hal tersebut.
\end{abstract}

Kata Kunci : Pengenalan, Orang Patut, Tradisi Melayu Riau.

\section{Pendahuluan}

Banyak orang yang salah menafsirkan budaya, padahal budaya suatu hal yang penting dalam meningkatkan perkembangan, kemajuan, suatu kelompok, suku, lingkungan, atau pribadi seseorang. Penafsiran yang kurang sesuai itu harus kita luruskan,bahwa budaya merupakan cerminan pola pikir seseorang dan begitu juga terhadap kelompok dan lingkungan, sehingga pada masa sekarang banyak orang menafsirkan bahwa budaya itu sama dengan seni, kreatifitas, atau suatu benda ditafsirkan hasil budaya.

Pengenalan yang akan dilaksanakan ini merupakan pengenalan kearah pandangan orang Melayu terhadap upaya pengenalan Orang Patut dalam tradisi Melayu Riau. Pengenalan budaya Melayu seperti Orang Patut dalam tradisi melayu Riau di SMP Negeri 3 Kecamatan Kampar 
Kiri Tengah belum pernah dilakukan. Sehingga bukan tidak mungkin Orang Patut dalam tradisi Melayu Riau yang merupakan salah satu kekayaan budaya orang Melayu akan punah di masa yang akan datang kalau permasalahan ini tidak diambil tindakan yang tepat untuk hal tersebut. Untuk itu,mengadakan kegiatan pengenalan tentang Orang Patut dalam tradisi Melayu Riau perlu dilakukan.

Pada saat ini bahwa faktor kemajuan peradaban dunia sebagai indikasi kemajuan berfikir umat manusia, sehingga kita pada masa sekarang ini hidup pada zaman yang serba maju yang instan dan kemajuan pola pemikiran yang semakin kritis. Peradaban yang semakin maju yang kita rasakan sekarang ini membawa perubahan di berbagai bidang kehidupan baik individu, keluarga, maupun dalam kehidupan bernegara dan bangsa.

Banyak di antara masyarakat itu menerima perubahan peradaban itu sebagai sesuatu yang biasa terjadi dan sebuah proses yang harus dijalani, diterima dan kehadirannya selalu menimbulkan berbagai perubahan dalam praktiknya, sehingga memaksa masyarakat budaya, mau tidak mau, sadar atau tidak sadar dihadapkan pada situasi yang sangat sulit antara menerima perubahan peradaban itu karena tidak ingin dianggap kolot atau menolak perubahan ini kendatipun dianggap primitif, konvensional, dan ortodoks.

seolah-olah meninggalkan kebudayaannya sedang sebagian orang ingin mempertahankannya sebagai sebuah warisan leluhur bersama (common heritage)yang wajib dijaga dan dilestarikan. Fenomena berikutnya adalah diakibatkan oleh mobilitas tanpa limit, dimana manusia tidak lagi dapat begitu saja dihempang dalam mobilitasnya. (Hans, $2000: 34$ )

Katakan saja, andai seseorang ingin bepergian ke tempat lain (negara Lain) maka tak seorangpun yang dapat menghempangnya apabila ia telah menetapkan bahwa ia harus berangkat. Keadaan ini juga mengakibatkan adanya perpaduan (assimilation) di tempat baru dimana ia berpijak, sehingga melahirkan penilaian apa yang diperoleh, diidolakan sebelumnya dengan dimana ia tinggal dan lihat.

Penilaian itu dapat saja memicu lahirnya interpretasi bahwa apa yang melekat pada dirinya ketika memutuskan untuk bepergian itu dinilai sebagai sesuatu yang kolot, tradisional dan tertinggal. Ia kemudian mengenakan berbagai atribut yang dianggap sebagai simbolisasi budaya maju seperti kritis, egoisme, dan materialistis. Kondisi lain adalah meningkatnya mobilitas sekolah antara negara dimana juga telah mempengaruhi pengakuan terhadap budaya lokalnya.

Keadaan dimana sipelaku diperhadapkan pada situasi dan alternatif yang kritis seperti itu telah menciptakan adanya anggapan bahwa budaya (lokal) tidak mampu menyaingi budaya (global) yang sedang mendunia. Namun demikian, bagi sebahagian orang tidak demikian, bahwa budaya lokal senantiasa akan bertahan (lestari) apabila sipelaku tidak membiarkan budaya (lokal)nya itu tidak tertindas, tidak tradisional dan tidak terbelakang apabila terdapat upaya sipelaku memajukan atau melakukan perubahan (innovation) dan penerapan (invention) terhadap apa yang disebut dengan budaya lokalnya itu. Lantas dalam situasi yang demikian ini dimana kemajuan zaman dan pola berfikir manusia tidak lagi dapat dibatasi, serta tingginya faktor komunikasi dan media penyampai, seberapa jauhkah budaya lokal itu dapat bertahan. (Darmawi, $2006: 23)$.

Mitra dalam kegiatan ini adalah siswa Sekolah Menengah Pertama yaitu SMP Negeri 3 Kec.Kampar Kiri Tengah. Rendahnya minat, perhatian, penghargaan, dan tingkat apresiasi budaya masyarakat serta kurangnya pengetahuan masyarakat terhadap Budaya terutama Budaya Melayu, hal itu disebabkan oleh berbagai hal, antara lain kurangnya minat baca mayarakat terhadap buku-buku budaya dan minimnya kegiatan pengabdian budaya kepada siswa di sekolah terlebih lagi budaya Melayu, serta belum ditemukannya metode paling tepat dalam membina budaya yang ada di lingkungan masyarakat.

Selain itu kurangnya pemahaman masyarakat terhadap budaya sehingga masyarakat tidak dapat menentukan jati diri mereka, yang lebih penting masyarkat tidak pernah menerima Sosialisasi Budaya terutama Budaya Melayu. Apalagi pengenalan Orang Patut dalam tradisi 
Melayu Riau yang mengandung nilai filosofis yang baik. Para siswa di SMP Negeri 3 Kec.Kampar Kiri Tengah belum mengenalnya.

Upaya yang seharusnya dilakukan untuk melestarikan Orang Patut dalam tradisi Melayu Riau ialah dengan mengadakan pengenalan dan memberikan pemahaman tentang Orang Patut dalam tradisi Melayu Riau.

Dengan adanya Masalah di atas yaitu kurangnya minat masyarakat di lingkungan sekolah terhadap pemahaman terhadap Orang Patut dalam tradisi Melayu Riau maka kami ingin meningkatkan minat tersebut guna mencapai tujuan tersebut, kami memandang perlu untuk menyelenggarakan kegiatan yang memiliki orientasi pada penumbuhan dan memupuk minat dan kreatifitas pelajar sekolah menengah atas.

Dalam kaitan ini, salah satu bentuk kegiatan yang dipandang memiliki orientasi ke arah itu adalah selalu mengadakan pengabdian dalam bentuk Sosialisasi budaya yang berdampak terhadap pemahaman mengenai Orang Patut dalam tradisi Melayu Riau di SMP Negeri 3 Kec. Kampar Kiri Tengah Kab.Kampar, dapat kiranya memberikan dampak yang positif terhadap perkembangan masyarakat ,Pelajar terhadap pelestarian Orang patut dalamtradisi Melayu Riau. Dengan pengenalan Orang patut dalamtradisi Melayu Riau kepada masyarakat ini setidaknya para pelajar Sekolah Menengah atas ini akan:

1. Memperluas wawasan dan cakrawala pemikiran serta memberikan dasar-dasar pengetahuan mengenai bidang-bidang ilmu yang berkaitan dengan nilai-nilai estetika budaya

2. Memperjelas motivasi dan orientasi budaya sehingga terbentuk kejelasan sikap.

3. Memperkenalkan perkembangan budaya dan membandingkan dengan budaya masyarakat tempatan.

4. merangsang semangat (etos) kreatif para peserta pada khususnya dan masyarakat pada umumnya,

5. mengembangkan kreativitas para peserta dalam pemahaman budaya

6. memupuk kecintaan dan sikap positif maupun minat dan bakat peserta khususnya dan masyarakat pada umumnya sehingga mereka memiliki kepekaan terhadap kemampuan kreasi/ekspresi.

\section{Pendekatan Pelaksanaan Program}

Untuk melaksanakan kegiatan pengabdian di sekolah banyak metode yang bisa dilakukan, namun kegiatan yang kami lakukan memakai metode berbentuk ceramah, tanyajawab atau diskusi. Sebelum kegiatan ini diadakan,

terlebih dahulu diadakan free test tentang pengenalan Orang Patut dalam tradisi Melayu Riau dilakukan dengan menggunakan beberapa metode seperti :

1. Metode Ceramah

2. Diskusi/tanya jawab

Metode ceramah yaitu suatu cara penyampaian bahan secara lisan oleh Tim di muka kelas, tim ini beranggotakan 3 orang. Peran seorang murid disini sebagai penerima pesan, mendengar memperhatikan, dan mencatat keterangan-keterangan tim. Metode ini layak dipakai tim bila pesan yang disampaikan berupa informasi, jumlah siswa terlalu banyak, dan tim adalah seorang pembicara yang baik.

Metode diskusi adalah suatu proses yang melibatkan dua individu atau lebih, berinteraksi secara verbal dan saling berhadapan, saling tukar informasi, saling mempertahankan pendapat dan memecahkan sebuah masalah tertentu. Penyampaian pelajaran dengan cara tim mengajukan pertanyaan dan murid menjawab atau penyajian pelajaran dalam bentuk pertanyaan yang harus dijawab, terutama dari tim kepada Siswa atau dapat juga dari Siswa kepada tim. 
Menurut Zakiyah Daradjat, metode praktek ini sama dengan metode percobaan yang biasanya dilakukan dalam mata pelajaran tertentu. Sedangkan menurut Departemen Agama yaitu praktek pengajaran yang melibatkan anak didik pada pekerjan akademis, pelatihan dan pemecahan masalah.

Materi yang akan diberikan kepada siswa SMP Negeri 3 Kecamatan Kampar Kiri Tengah Kab.Kampar adalah tentang pengenalan Orang Patut dalam tradisi Melayu Riau.

\section{Pelaksanaan Program}

Kegiatan ini dilakukan di SMP Negeri 3 Kecamatan Kampar Kiri Tengah Kabupaten Kampar pada tanggal 18 November 2020 yang dihadiri 21 orang peserta, berdasarkan kegiatan yang telah dilaksanakan dengan baik dan beberapa hasilnya telah diperoleh.

Pada tahap pertama, peserta dibagikan kuosioner pretest untuk diisi peserta dan memberikan waktu selama lebih kurang 10 menit untuk mengisinya. Setelah mereka mengisi dan menyerahkan ke panitia, kami dari tim pengabdian diberikan kesempatan untuk menjelaskan tentang "Pengenalan Orang Patut dalam Tradisi Melayu Riau."

Pada tahap kedua ini peserta diajak untuk bisa memahami dan memperhatikan materi yang dijelaskan oleh tim pengabdian, hal ini berlangsung sekitar 90 menit secara bergantian yakni Amanan, Hermansyah, dan Juswandi sebagai moderator.

Pada tahap ketiga peserta dipersilahkan untuk mengajukan pertanyaan dan menyampaikan permasalahan yang timbul dalam upaya memperkenalkan Orang Patut dalam tradisi Melayu Riau, mereka rata - rata mengajukan pertanyaan dan keluhan sebagai berikut :

Evaluasi diperoleh dari hasil olahan kusioner dengan memberikan kusioner kepada siswa orang peserta sebelum dan sesudah pelatihan. Dari jawaban kusioner tersebut dapat diketahui bagaimana pemahaman peserta terhadap materi yang diberikan selama pengabdian. Untuk lebih jelasnya dapat dilihat hasil rekapitulasi jawaban - jawaban responden.

Tabel 1 Hasil Rekapitulasi kusioner Pretest

\begin{tabular}{|c|l|c|c|}
\hline No & \multicolumn{1}{|c|}{ Pertanyaan } & Tidak & Ya \\
\hline 1 & $\begin{array}{l}\text { Apakah anda pernah mengikuti pengabdian pengenalan } \\
\text { Orang Patut dalam tradisi Melayu Riau? }\end{array}$ & 21 & 0 \\
\hline 2 & $\begin{array}{l}\text { Apakah anda tau tentang Orang Patut dalam tradisi } \\
\text { Melayu Riau? }\end{array}$ & 21 & 0 \\
\hline 3 & $\begin{array}{l}\text { Apakah anda pernah mengikuti pengabdian tentang } \\
\text { Orang Patut dalam Tradisi Melayu Riau? }\end{array}$ & 21 & 0 \\
\hline 4 & Apakah anda sudah pernah menerima kegiatan seperti ini? & 21 & 0 \\
\hline 5 & $\begin{array}{l}\text { Apakah anda sudah tau tentang Orang Patut dalam } \\
\text { Tradisi Melayu Riau? }\end{array}$ & 21 & 0 \\
\hline 6 & $\begin{array}{l}\text { Apakah anda sudah tau Siapa saja yang di katakan Orang } \\
\text { Patut dalam Tradisi Melayu Riau? }\end{array}$ & 21 & 0 \\
\hline 7 & $\begin{array}{l}\text { Apakah anda tau Orang Patut dalam Tradisi Melayu } \\
\text { Riau Siapa? }\end{array}$ & 21 \\
\hline 8 & $\begin{array}{l}\text { Apakah anda sudah tau apa peran Orang Patut dalam } \\
\text { Tradisi Melayu Riau? }\end{array}$ & 21 & 0 \\
\hline 9 & $\begin{array}{l}\text { Apakah anda akan mempelajari pungsi Orang Patut dalam } \\
\text { tradisi Melayu Riau? }\end{array}$ & 21 \\
\hline 10 & $\begin{array}{l}\text { Bagaimana pendapat anda tentang Orang Patut dalam } \\
\text { Tradisi Melayu Riau? }\end{array}$ & 21 \\
\hline
\end{tabular}


Tabel 2 Hasil Rekapitulasi kusioner Post Test

\begin{tabular}{|c|l|c|c|c|}
\hline No & \multicolumn{1}{|c|}{ Pertanyaan } & Ya & Tidak & Peningkatan \\
\hline 1 & $\begin{array}{l}\text { Apakah anda pernah mengikuti pengabdian } \\
\text { pengenalan Orang Patut dalam Tradisi Melayu } \\
\text { Riau? }\end{array}$ & 21 & 0 & $100 \%$ \\
\hline 2 & $\begin{array}{l}\text { Apakah anda tau tentang Orang Patut dalam } \\
\text { Tradisi Melayu Riau? }\end{array}$ & 21 & 0 & $100 \%$ \\
\hline 3 & $\begin{array}{l}\text { Apakah anda pernah mengikuti pengabdian } \\
\text { tentang Orang Patut dalam Tradisi Melayu } \\
\text { Riau? }\end{array}$ & 21 & 0 & $100 \%$ \\
\hline 4 & $\begin{array}{l}\text { Apakah anda sudah pernah menerima kegiatan } \\
\text { seperti ini? }\end{array}$ & 21 & 0 & $100 \%$ \\
\hline 5 & $\begin{array}{l}\text { Apakah anda sudah tau tentang Orang Patut } \\
\text { dalam Tradisi Melayu? }\end{array}$ & 21 & 0 & $100 \%$ \\
\hline 6 & $\begin{array}{l}\text { Apakah anda sudah tau Siapa saja yang } \\
\text { dikatakan Oang Patut dalam Tradisi Melayu } \\
\text { Riau? }\end{array}$ & 21 & 0 & $100 \%$ \\
\hline 7 & $\begin{array}{l}\text { Apakah anda tau Orang Patut Dalam Tradisi } \\
\text { Melayu Riau? }\end{array}$ & 21 & 0 & $100 \%$ \\
\hline 8 & $\begin{array}{l}\text { Apakah anda sudah tau Apa peran Orang Patut } \\
\text { dalam Tradisi Melayu Riau? }\end{array}$ & 21 & 0 & $100 \%$ \\
\hline 9 & $\begin{array}{l}\text { Apakah anda akan Mempelajari Fungsi Orang } \\
\text { Patut dalam Tradisi Melayu Riau? }\end{array}$ & 21 & 0 & $100 \%$ \\
\hline 10 & $\begin{array}{l}\text { Bagaimana pendapat anda tentang Orang Patut } \\
\text { dalam Tradisi Melayu Riau? }\end{array}$ & 21 & 0 & $100 \%$ \\
\hline
\end{tabular}

Berdasarkan tabel di atas dapat disimpulkan bahwa hasil post test menujukkan peningkatan pengetahuan ada pada semua point pertanyaan : yakni tentang pada pertanyaan pertama $100 \%$ artinya orang peserta belum pernah mengikuti pengabdian tentang Peralatan Musik Tradisional Melayu Riau sehingga dengan kegiatan ini mereka bisa memahami pentingnya memperkenalkan Orang Patut dalam Tradisi Melayu Riau di sekolah yang harus dikembangkan di masa yang akan datang. Mereka berjanji akan lebih memperkenalkan Orang Patut dalam tradisi Melayu Riau. Dari 21 orang peserta seluruhnya belum mengetahui cara memperkenalkan OrangPatut dalam tradisi Melayu Riau. Dari kegiatan ini mereka mendapatkan gambaran dan mengetahui tentang OrangPatut dalam Tradisi Melayu Riau. Maka peserta yang hadir dapat memahami bahwa gerakan Merkenalkan Orang Patut dalam Tradisi Melayu Riau di sekolah memang penting diterapkan.

Berdasarkan tabel diatas dapat disimpulkan bahwa dengan dilakukannya pengabdian pengenalan Orang Patut dalam Tradisi Melayu Riau peserta bisa memahami tugas dan fungsi siswa dalam memperkenalkan Orang Patut dalam Tradisi Melayu Riau yang mempunyai manfaat yang sangat baik.

Hal tersebut mereka sampaikan kepada penyaji, dengan permasalahan di atas penyaji menjelaskan bahwa keterbatasan yang mereka ungkapkan tersebut berarti pembinaan tentang Pengenalan Orang Patut dalam Tradisi Melayu Riau kepada kita bersama harus dilatih dan dianjurkan selalu membuat hal - hal yang inovatif agar siswa tertarik untuk memahami dan menerapkannya. Peran OSIS dan guru di sekolah dalam masyarakat harus bisa menunjukkan bagaimana dia memberikan arahan agar murid, mayarakat, bisa meningkatkan / mengadakan buku buku di sekolah tentang Musik Melayu tersebut dan kegiatan yang dapat membantu siswa di sekolah seperti : 
1. Guru memberi kesempatan kepada siswa dengan memberi kesempatan Mempelajari Orang Patut dalam Tradisi Melayu Riau pada mata pelajaran tertentu (Kesenian/ Seni Budaya).

2. Memberi tugas kepada siswa untuk mencari siapa saja yang dikatakan Orang Patut dalam Tradisi Melayu Riau yang sering digunakan oleh masyarakat.

3. Sekolah mengadakan wadah - wadah atau sarana untuk mempelajari Orang Patut dalam Tradisi Melayu Riau sehingga para siswa di sekolah dengan cara bekerja sama dengan guru wali kelas.

4. Guru juga bertanggung jawab bagaimana memberdayakan organisasi - organisasi yang ada di sekolah dengan cara membuat semenarik mungkin bagi siswa, sehingga mereka tertarik untuk mempelajari Orang Patut dalam Tradisi Melayu Riau.

5. Memberi tugas kepada siswa untuk mencari siapa saja yang dikatakan Orang Patut dalam Tradisi Melayu Riau yang sering digunakan oleh masyarakat.

6. Sekolah mengadakan wadah - wadah atau sarana untuk mempelajari Orang Patut dalam Tradisi Melayu Riau sehingga para siswa di sekolah dengan cara bekerja sama dengan guru wali kelas.

7. Guru juga bertanggung jawab bagaimana memberdayakan organisasi - organisasi yang ada di sekolah dengan cara membuat semenarik mungkin bagi siswa, sehingga mereka tertarik untuk mempelajari Orang Patut dalam Tradisi Melayu Riau.

Siswa SMP Negeri 3 Kec. Kampar kiri Tengah Kampar Kampar mengikuti kegiatan pengabdian dan mulai mengerti, memahami tentang Orang Patut dalam Tradisi Melayu . Melihat keseriusan para siswa mengikuti kegiatan, pemahaman mereka tentang Orang Patut dalam Tradisi Melayu Riau semakin baik, mereka sudah bisa membedakan Antara Kelompok yang satu dengan yang lainnya

\section{Refleksi Capaian Program}

1. Kegiatan pengenalan Orang Patut dalam tradisi Melayu Riau di SMP Negeri 3 Kecamatan Kampar Kiri Tengah Kabupaten Kampar ini adalah sangat tepat dilaksanakan karena dapat menarik minat siswa dalam memiliki beberapa keunggulan di antaranya Materi ajar yang disampaikan sesuai dengan kebutuhan dan lingkungan siswa.

2. Dari perhitungan persentasi yang dapat diperoleh berdasarkan hasil pratest $100 \%$ dari siswa SMP Negeri 3 Kecamatan Kampar Kiri Tengah belum pernah mengikuti pengenalan Orang Patut dalam Tradisi Melayu Riau.

3. Dari perhitungan persentasi yang dapat diperoleh berdasarkan hasil posttest $100 \%$ dari siswa SMP Negeri 3 Kec. Kampar Kiri Tengah belum pernah mengikuti pengenalan Orang Patut dalam Tradisi Melayu Riau, Materi penyuluhan sesuai dengan judul Pengabdian.

\section{Penutup}

1. Sepatutnya guru yang mengajarkan seni budaya, Sejarah juga sangat paham tentang Orang Patut. Guru yang mengajarkan betul-betul terlatih dan memahami tentang Orang Patut dalam Tradisi Melayu Riau. Dari pengamatan tim para siswa perlu dorongan dan dukungan dalam memamahami tentang Orang Patut dalam Tradisi Melayu Riau

2. Sangat diperlukan keseriusan dari sekolah untuk mengadakan ektrakurikuler di bidang Budaya Melayu, khususnya tentang Orang Patut dalam Tradisi Melayu Riau.

3. Jangan mengganggap Budaya Melayu (khususnya Orang Patut dalamTradisi Melayu Riau) hanya sebagai Simbol dari, kehidupan belaka, karena budaya Melayu memiliki nilai-nilai moral yang luhur.

4. Materi lokal hendaknya benar-benar dipahami guru dan murid supaya lebih bermamfaat dan dapat diaplikasikan dalam kehidupan.

5. Sepatutnya guru yang mengajarkan seni budaya, Sejarah juga sangat paham tentang Orang Patut dalam tradisi Melayu Riau, dan mengetahui peranannya dalam kehidupan bermasarakat. 


\section{Daftar Pustaka}

Dewan Bahasa dan Pustaka.1990. Kamus Dewan Edisi Ketiga.Jakarta:Balai Pustaka.

Darmawi, Ahmad. 2006. Sastra Lisan Nandung. Indragiri Hulu Pekanbaru: Dinas Kebudayaan Kesenian Dan Kepariwisataan Provinsi Riau.

Effendy, Tenas.1990.Pandangan Orang Melayu Terhadap Anak. Pekanbaru: Badan Pembina Daerah Riau.

.2004. Tunjuk Ajar Melayu. Yogyakarta : Adicita Karya Nusa.

2005. Tunjuk Ajar Melayu Tentang Hidup Hemat dan Cermat.Pekanbaru Lembaga Adat Melayu Riau.

2005. Pantun Nasihat.Yogyakarta : Adicita Karya Nusa. Clifford Geertz. 1992. Tafsir Kebudayaan.Yogyakarta: Kanisius

Tenas Effendy.

2013. Lambang dan Falsafah dalam Seni Bina Melayu. Pekanbaru :Yayasan

Gazalba, Sidi.1981.Sistimatika Filsafat Pengantar pada teori Nilai Buku IV.Jakarta: Bulan Bintang.

Hans J. Daeng. 2000. Manusia Kebudayaan dan Lingkungan Tinjauan Antopologi, Yogyakarta. Pustaka Pelajar

Hamidy, UU dan Muchtar Ahmad. 1984. Orang Patut. Pekanbaru : Bumi Pustaka.

Kadir, Helmiati, dkk. 2014. Peralatan Musik Tradisional Melayu Riau. Pekanbaru : Dinas Kebudayaan dan Pariwisata Provinsi Riau Bekerjasama dengan Penerbit Asa Riau.

Lutfi, Muchtar.1997. Sejarah Riau. Pekanbaru: Percetakan Riau. 